\title{
Scheckler to Retire as Chair of the SHEA Publications Committee
}

The charge to the Publications Committee of SHEA is to oversee and make policy recommendations to the Board concerning all formal SHEA contracts with publishers. Over the past five years, under the soon-to-beconcluded term of Committee Chair Bill Scheckler, this has involved work with Slack, Inc., in creatively developing an improved relationship between the Society and the publisher of Infection Control and Hospital Epidemiology Since the contract was signed with Slack, Inc., in 1991, income to the Society has been substantial and is equivalent to $\$ 70$ per member per year. Eli Abruytn will direct the
Publications Committee in 1994. His prior knowledge of the publication process already has contributed greatly to our successful negotiations with Slack, Inc.

In addition to establishing a satisfactory working relationship with our publisher, the financial arrangements negotiated in the contract have provided the Society with an increasingly firm financial base. Another important accomplishment for the Publications Committee was its successful collaboration with Slack, Inc., in replacing the retiring first editor of our journal, Richard Wenzel, with our new editor, Michael Decker.
In addition to its work on our contractual relationship with Slack, Inc., the Publications Committee has provided oversight and advice for the Board for the monthly "SHEA News" page in Infection Control and Hospital Epidemiology and for the freestanding, quarterly SHEA Newsletter. After his completed term, the first "SHEA News" and SHEA N ewsletter editor, Bob Weinstein, was replaced by current editor, C. Glen Mayhall. For details of the successful tenure of Dr. Scheckler as Chair of the Publications Committee, watch for your December 1993 issue of the SHEA Newsletter.

\section{Status of SHEA Position Paper on Hepatitis C Occupational Exposures in HCWs}

Hepatitis $C$ virus is the major cause of non-A, non-B hepatitis and is a source of concern among healthcare workers exposed to blood and body fluids. Because there are no clear guidelines on hepatitis $\mathrm{C}$ testing and appropriate management when such an exposure occurs, the SHEA Board earlier this year directed that a SHEA position paper be developed to address these issues. To find out what current policies are, Ludwig Lettau of Greenville Hospital, South Carolina, chair of this position paper committee, soon will send to SHEA members a survey questionnaire. This survey will seek information on whether source patients involved in an employee exposure are tested for $\mathrm{HCV}$, which screening test is used, whether supplementary tests are used for confirmation, the cost of these tests, and whether postexposure immunoglobulin is offered as prophylaxis. The results of the survey will be incorporated into the position paper and will help define standard practice. Please complete and return the questionnaire to Dr. Lettau promptly. The Hepatitis C Position Paper Committee appreciates your cooperation.

Brief items of interest for the SHEA N ews or N ewsletter may be sent to $C$. Glen Mayhall, M D, SHEA, N ewsletter Editor, D ivision of Infectious D iseases, D epartment of $M$ edicine, U niversity of Tennessee, M emphis, 956 Court A ve., M emphis, TN 38163; FAX (901) 528-5854. Copy should be typed, doublespaced, and should not exceed five pages. 